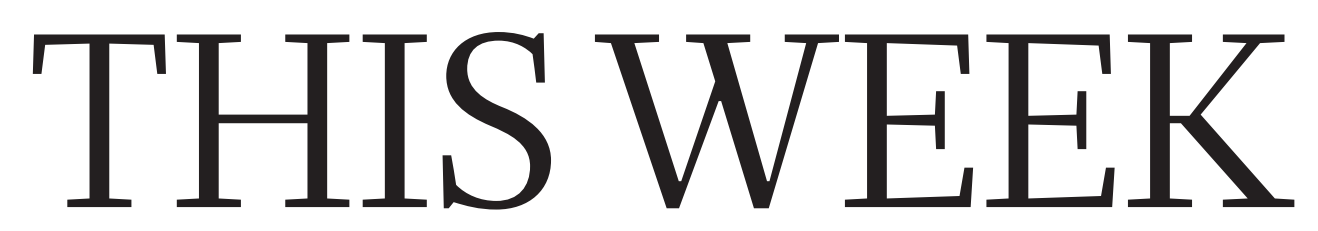

EDITORIALS

GHOST STORY The sinister tale of lost and abandoned fishing gear $\mathbf{p . 6 1 0}$
WORLD VIEW Beware the transfer of innocent people's DNA to crime scenes $\mathbf{p . 6 1 1}$
PLAGUE Ancient remains show that disease was around early $\mathbf{p . 6 1 3}$

\title{
Power struggle
}

\section{The UK government's decision to subsidize a nuclear power station while cutting support for renewables is short-sighted.}

$\mathrm{T}$ The English poet William Blake once wrote that "Energy is an eternal delight". But then poets have rarely been charged with keeping the lights on. Some 200 years later, energy — and how to produce and harness it - is on track to become the defining problem of a generation.

The latest dark satanic mill on the horizon in Blake's green and pleasant land is a shiny new nuclear power station - confirmed last week after years of plotting. It will be the first built in the United Kingdom this century, and is one of the most significant nuclear deals worldwide since the meltdown at the Fukushima Daiichi nuclear power plant in Japan in 2011.

As Chinese President Xi Jinping — in the United Kingdom for a state visit - was paraded around a series of picture-book British locations, it was announced that China was taking a 33.5\% stake in the Hinkley Point C nuclear plant. French power company EDF will own the remaining $66.5 \%$.

Supported by billions of pounds of Chinese investment, the plant should provide 3.2 gigawatts of power when it fires up as planned in 2025. But never mind the output: feel the cost.

The UK government has agreed a price with the investors of at least $£ 89.50$ (US\$137) in 2012 terms for every megawatt hour of power produced by the plant. This is roughly double the current market cost, but the government claims - with a little poetic licence of its own that it "is competitive with other large energy sources such as gas and offshore wind".

The Conservative government also noted that this would mean abandoning the policy of several previous administrations that there should be no public subsidy for new nuclear power.

In reality, it had little choice. (The previous administrations had no problems sticking to the line, because they had no new nuclear power to subsidize.) Nuclear power plants are among the single most expensive items that governments can buy, and as Britain has allowed its home-grown nuclear expertise to dwindle, so it has lost the chance to bury the exact cost in a tangle of public expenditure. Whether the money comes directly from the public as artificially high electricity bills, or indirectly through the public purse, British politicians last week admitted that the technology simply cannot pay for itself.

In doing so, they have been criticized - there are plenty of opponents who argue, with some justification, that this nuclear deal is a poor one for Britain. But in a way, the new-found candour about the costs does at last make the debate about energy a more honest one. Most power industries, to a greater or lesser extent, need a financial leg-up.

Hinkley Point $\mathrm{C}$ will cost at least $£ 18$ billion. And that does at least buy a reduction in greenhouse-gas emissions compared with one carbon-heavy alternative for baseload generation: coal. But the UK government has done little to stress that point - it is hard for it to do so while systematically cutting off other low-carbon forms of electricity at the knees.
Last year, renewable energy sources supplied a record 19\% of UK electricity (the global figure is around 22\%), but the same government that is committed to subsidizing Hinkley Point $\mathrm{C}$ has set out to slash subsidies for renewables. Trade associations say that thousands of jobs could go. Businesses face collapse as sections of the solar industry deal with $87 \%$ cuts in their subsidies, and onshore wind is under threat. Perversely, ministers justified the sacrifice of these growing

"Mostpower
industries, to
a greater or
lesser extent,
need a financial
leg-up."
clean-energy sources by pointing to increasing public support for them.

The United Kingdom is far from alone in struggling to balance short-term financial prudence with long-term environmental protection. Earlier this month, the International Energy Agency reported that renewable energy accounts for $45 \%$ of new power capacity added globally in 2014. But it warned that the rate of growth for renewables was slowing because of policy problems and uncertainties - especially in Europe and Japan.

UK energy and climate-change minister Andrea Leadsom used the ugly word "trilemma" last week to describe the energy issue facing the United Kingdom: the need to reduce carbon emissions, to maintain supplies and to keep bills down.

There is another trilemma, popular among project managers: the need for any project to be good, fast and cheap. The classic response could have been written for energy policy: 'pick two'.

\section{Burst bubbles}

\section{Two medical-technology companies illustrate the ups and downs of innovation.}

F rom time to time in most industries, the conventional approach is challenged by upstarts. Often backed by entrepreneurs and investors, these firms promise to use new technology to disrupt, overturn and revolutionize. Some succeed and some do not, and there are fields in which the challenge to newcomers is proving stiffer than others. One of these is health care, and events over the past week or so demonstrate both the difficulties and the opportunities.

Theranos and 23andMe are two medical-technology companies with their origins in Silicon Valley. Both have made headlines recently. Their stories may seem similar. But the differences offer an important lesson for would-be health disruptors: this industry can change, just not as quickly as entrepreneurs and their investors might hope, and only if those offering the change can also offer data to back up their claims. 